\title{
Yield response of a polycropping system with maize to fermented foliar fertilizers
}

\section{Efecto de biofertilizantes foliares sobre el rendimiento de un policultivo con maíz}

\author{
Roland Ebel \\ Universidad Autónoma del Estado de México, México \\ roland.ebel@gmx.com \\ (D) http://orcid.org/0000-0002-4391-0245
}

Recepción: 29 de noviembre de 2018

Aprobación: 07 de junio de 2019

\begin{abstract}
Anaerobically fermented foliar fertilizers (FFF) are made of local plant or animal inputs. The impact of four different FFF formulations on the output of an intercropping system with fava bean, maize, and squash was assessed in the Toluca Valley, Central Mexico. A fertilizer made of cow manure and fermented agave cactus juice had an elevated $\mathrm{N}$ and $\mathrm{P}$ content and resulted in the highest maize output. A fertilizer made of cow manure and maize stalks contained most $\mathrm{K}$ and delivered the highest squash yield. A FFF made of cow manure and stinging nettle delivered the highest fava bean output. There are no ideal formulations of FFF, but their formulation depends on available resources and treated crops.
\end{abstract}

KEYWORDs: Organic plant nutrition, biofertilizer, anaerobic digestion, sustainable horticulture, Mexico.

\section{RESUMEN}

Los biofertilizantes foliares (BFF) se elaboran a partir de insumos locales de plantas o animales. En el valle de Toluca se evaluó el impacto de cuatro diferentes BFF sobre un policultivo con maíz, haba y calabaza. De todos los BFF comparados, el elaborado de estiércol de ganado y pulque mostró el mayor contenido de $\mathrm{N}$ y $\mathrm{P}$ y resultó en la mayor cosecha de maíz. Un fertilizante hecho de estiércol de vaca y mazorcas de maíz mostró más K y estimuló el rendimiento de la calabaza. Otro BFF, elaborado de estiércol de vaca y ortiga picada, generó la mayor cosecha de haba. No existen recetas estándar para los BFF, sino su formulación apropiada varía según los recursos disponibles y los cultivos tratados.

Palabras Clave: nutrición vegetal orgánica, biofertilizante, horticultura sustentable, México.

\section{INTRODUCTION}

\section{1. Definition}

Fermented foliar fertilizers, FFF (also known as fermented leaf fertilizers, FLF), describe anaerobically digested animal and plant residues used as organic foliar fertilizers. Essentially, FFF nourish crops directly (Ebel \& Kissmann, 2019). In Latin America, FFF are widely called biol., although this term is also used for the (partially overlapping) concept of bio-fertilizers, which do not directly provide nutrients to the plants but increase the soil fertility through an enhancement of the soil microorganism activity (Chojnacka, 2015).

The use of FFF is viable for all kinds of annual and perennial crops (Galindo et al., 2007). Hence, their use in horticultural production is most common. Increased yields because of the use of FFF are proved for bean (Bejarano \& Méndez, 2004), maize (Vázquez et al., 2014), and spinach (Siura et al., 2009). If FFF are used, compared to conventional solid organic fertilizers, there is a remarkable immediate nutrient supply, high enough to meet the micronutrient demand of numerous horticultural and ornamental plants (Burnett et al., 2016). These fertilizers are normally produced on-farm (Ito, 2006). Therefore, their composition is not specified but depends on the resources available on a farm and the demands of the therewith treated crops. 


\subsection{Formulation}

Despite a diverse potential resources for generating FFF, there are four principal components every FFF consists of: Organic nutrient sources, energy sources, microorganism sources (inoculants), and water. Concerning nutrient sources, cattle manure is a common source. Potential alternatives are manures of other animals as well as vegetative nutrient sources such as stinging nettle, fruit mash, pods of legumes, oat and wheat groats, arnica, or comfrey. Pulverized charcoal can be added to nourish microorganisms. For energy sources, cane molasses or unrefined sugar are the standard ingredients. Alcoholic beverages may be used as well. Fresh cow milk is the most common microorganism source. Further options include forest humus, compost, fermented food, rice, and corncobs. Vegetative ash or rock flour may be added to raise the nutrient content. The addition of lime ensures a neutral pH (Ebel, 2017).

The most basic FFF formulation, called from here on the standard formulation, consists of $50 \mathrm{~kg}$ fresh cow manure, $4 \mathrm{~L}$ fresh cow milk, $4 \mathrm{~L}$ cane molasses, and $150 \mathrm{~L}$ rainwater, which are anaerobically digested to produce approximately 200 L FFF (Table 1).

\section{TABLE 1}

Nutrient content of standard FFF formulations after a minimum of 30 days of digestion

\begin{tabular}{|c|c|c|c|c|c|c|c|c|c|c|}
\hline Formulation & $\mathrm{N}(\mathrm{a})$ & $\mathrm{P}$ & $\mathrm{K}$ & $\mathrm{Ca}$ & $\mathrm{Mg}$ & $\mathrm{Fe}$ & $\mathrm{Mn}$ & $\mathrm{Cu}$ & $\mathrm{Zn}$ & Reference \\
\hline & Ppm & --- & --- & --- & --- & --- & --- & --- & --- & \\
\hline $\mathrm{S}(\mathrm{b})$ & 2000 & 733 & 4531 & 2042 & 486 & & & & & (Ito, 2006) \\
\hline $\mathrm{SSY}(\mathrm{c})$ & 818 & 93 & 2037 & 191 & 483 & & 4 & 1 & 1 & (Galindo et al., 2007) \\
\hline$P(d)$ & 1200 & 50 & 340 & & & & $<10$ & & $<10$ & (Lee et al., 2012) \\
\hline $\mathrm{SA}^{(\mathrm{e})}$ & 480 & 28 & 1651 & 978 & 348 & 8 & & & & (Zagoya et al., 2015) \\
\hline
\end{tabular}

Source: own elaboration.

Note: (a) Total N; (b) Standard formulation; (c)Standard formulation, salts and yeast added; (d) FFF made of pig manure; (e) Standard formulation, ash added.

\subsection{Preparation and application}

Usually, self-made biodigestors (made of adapted barrels) are used to mineralize the nutrients in the raw material, but large-scale industrial production is conceivable. Before digestion, all vegetative material must be shredded to a length of a maximum of $2 \mathrm{~cm}$. The biodigestor is then filled with the shredded material, the fresh animal excrements, and $100 \mathrm{~L}$ water. Ash may be added. Simultaneously, the energy sources and the milk are mixed with $20 \mathrm{~L}$ water in a separate container and subsequently added to the digestor. Afterward, the barrel is filled with water (leaving enough space for the digestion gases) and locked (Ebel \& Kissmann, 2019). The digestion process lasts two to eight weeks (Ito, 2006). During digestion, the bio-digestor must be protected from sunlight as it stimulates the oxidation of the organic compounds (Restrepo \& Hensel, 2009). After locking the digestor, aerobic microorganisms cause a quick consumption of the remaining oxygen, and anaerobic digestion starts immediately (Siura et al., 2009). Thereby, organic substances are converted into humic and non-humic biomass, minerals, and volatile inorganic compounds (Gerardi, 2003). Before applying them, FFF must be diluted 1:20 with water. During a crop cycle of rainfed bean and maize production, six to eight applications of FFF are recommended (Restrepo \& Hensel, 2009).

\subsection{Nutrient content and absorption}

There is evidence that leaves can absorb inorganic nutrients supplied in aqueous forms (Kannan, 2010). Foliar-applied nutrients are lipid-insoluble ions and, therefore, enter the plant metabolism following an aqueous 
pathway through a leaf's cuticular wax or the stomata. The ultimate parameter controlling the penetration of foliar-applied substances is the intrinsic permeability of the leaf surface. This is a passive process driven by concentration gradients (Fernández \& Eichert, 2009) and stimulated by light and soil moisture (Fageria et al., 2009).

A standard FFF formulation (Table 1) contains 2000 ppm N, 733 ppm P, and 4531 ppm K. Most FFF show a slightly acidic $\mathrm{pH}$ (Zagoya et al., 2015). The electric conductivity of FFF is around $5 \mathrm{dS} \mathrm{m}^{-1}$ (Orellana et al., 2013).

\section{Justification}

Although conventional monocropping is economically predominant, traditional polycropping still characterizes small-scaled farms in central Mexico. Apart from the traditional Mesoamerican milpa polycropping system (maize, bean, and squash), the polycropping of maize, fava bean, and squash is common (Ebel et al., 2017). Increased agrobiodiversity of a production system has multiple benefits: increased yield; a longer harvest period; a diversified production; time-efficient crop management; stimulation of the soil microflora (Gliessman, 1985); the maximization of the exploitation of available nutrients and water; sequestration of atmospheric carbon; as well as improved resilience to pests and meteorological perturbations (Altieri, 1994). In short, polycropping is an excellent approach to increase the sustainability of farming systems.

The use of FFF is an equally sustainable plant nutrition strategy. Although FFF have been used in crops such as maize and legumes (Zagoya et al., 2015), which are frequently intercropped, evidence of their use in polycropping systems is scarce. Thus, FFF are prevailingly used in monocropped vegetables (Ito, 2006). Furthermore, the sustainability of FFF is based on the use of locally available resources. As FFF are most common in the Latin American tropics, common formulations are based on resources (such as molasses), which are not available in the template Central Mexican highlands or similar climates.

The present trial deals with FFF made of resources available in the Toluca Valley, located in the Mexican Highlands. It assesses the impact of their application on the yield and growth of a polycropping system consisting of maize, fava beans, and squash. Fava beans were chosen due to their economic significance in the region as well as their adaptation to the prevailing template climate.

\section{Materials and methods}

\section{1. Location}

The trial was implemented in 2016 at the Campus El Cerrillo Piedras Blancas of the Autonomous University of the State of Mexico ( $92^{\circ} 42^{\prime} \mathrm{E}$ and $19^{\circ} 24^{\prime} \mathrm{N}$ ) in the Valley of Toluca, central Mexico, $18 \mathrm{~km}$ north of the city of Toluca, at an altitude of $2611 \mathrm{~m}$ above sea level. There is a dry-winter highland climate (Instituto Nacional de Estadística y Geografía, 2018). In the city of Almoloya de Juárez, located $9.5 \mathrm{~km}$ from the place of the experiment, the average temperature is $13.3^{\circ} \mathrm{C}$ and the annual precipitation $744 \mathrm{~mm}$ (Comisión Nacional del Agua, 2018). Annual frost is an environmental limitation for agriculture in this area, where rainfed maize is the most common cropping system. The area lies on extrusive igneous rocks. The prevailing soil is vertisol.

\section{2. Experimental set-up}

There were six treatments with eight replications each; hence, the field was divided into 48 plots of $100 \mathrm{~m}^{2}$, arranged in a randomized block system. The treatments differed in terms of fertilization: After initial incorporation of cow manure to the entire field four weeks before seeding, different FFF were applied in four treatments; a further treatment was fertilized with bokashi, a solid organic fertilizer; the control treatment did not receive additional fertilization management. 


\section{3. Formulation and preparation of examined fertilizers}

The preparation of all four experimented FFF was based on the standard formulation as defined by Restrepo \& Hensel (2009), which was modified based on farmer recommendations regarding the availability of the required resources in the region (Table 2).

TABLE 2

Raw material used for the preparation of FFF compared in the trial

\begin{tabular}{|llllll}
\hline & $\begin{array}{l}\text { Nutrient and micro- } \\
\text { organism sources (a) }\end{array}$ & Energy sources & Inoculants & $\begin{array}{c}\text { Sources of organic } \\
\text { matter }\end{array}$ & Additional ingredients \\
\hline B1 & Cow manure, ash & Unrefined brown sugar & Milk & Maize stalks & Rainwater \\
B2 & Cow manure, ash & Pulque (b) & Oat bran, yeast & $\begin{array}{l}\text { Forestal soil, oat } \\
\text { straw, charcoal }\end{array}$ & Rainwater \\
B3 & $\begin{array}{l}\text { Cow manure, stinging } \\
\text { nettle }\end{array}$ & Refined sugar & Milk, beer & $\begin{array}{l}\text { Forestal soil, maize } \\
\text { stubbles }\end{array}$ & Lime, rainwater \\
B4 & Chicken dung & Unrefined brown sugar & Milk, yeast & Fruit waste (c) & Rainwater \\
\hline
\end{tabular}

Source: own elaboration.

Note: (a) The categorization is approximate: cow manure, for example, is primarily a source of nutrients but also provides microorganisms and organic matter; (b) Fermented agave cactus juice; (c)Diverse fruits (except citrus).

For all experimented FFF (Table 3), fresh animal excrements and fresh milk were used. Maize stalks and stubbles, as well as oat bran and straw, were ground before being added to the fermenter. Fresh stinging nettle (only leaves) and the fruit waste were squashed manually to a size of a maximum of $2 \mathrm{~cm}$. The charcoal was smashed, and the soil was sieved before adding. Yeast and sugar were each dissolved in $2 \mathrm{~L}$ warm water before adding them to the respective FFF. Ash and lime were both dissolved in $4 \mathrm{~L}$ rainwater. Immediately after fermentation, they were added to the FFF.

TABLE 3

Amounts of resources used for the preparation of $1 \mathrm{~L}$ of the experimented FFF

\begin{tabular}{|c|c|c|c|c|c|c|c|c|}
\hline & Manure & Ash (a) & Sugar & Cow milk & Other liquids & Herbal inputs & Other inputs & Rain-water \\
\hline & $\mathrm{g} \mathrm{L}^{-1}$ & $\mathrm{~g} \mathrm{~L}^{-1}$ & $\mathrm{~g} \mathrm{~L}^{-1}$ & $\mathrm{ml} \mathrm{L}^{-1}$ & $\mathrm{ml} \mathrm{L}^{-1}$ & $\mathrm{~g} \mathrm{~L}^{-1}$ & $\mathrm{~g} \mathrm{~L}^{-1}$ & $\mathrm{ml} \mathrm{L}^{-1}$ \\
\hline B1 & 250 (b) & 20 & $20(c)$ & 20 & & $25(\mathrm{~d})$ & & 900 \\
\hline $\mathrm{B} 2$ & $250(b)$ & 20 & & & $10(\mathrm{e})$ & $25(\mathrm{f}), 15^{(\mathrm{g})}$ & $5^{(\mathrm{h})}, 5^{(\mathrm{i})}, 5^{(\mathrm{j})}$ & 900 \\
\hline B3 & $150(b)$ & & $20(\mathrm{k})$ & 10 & $10(1)$ & $100(\mathrm{~m}), 25(\mathrm{n})$ & $10^{(\mathrm{j})}, 10^{(\mathrm{o})}$ & 900 \\
\hline B4 & $75(\mathrm{p})$ & & $10(\mathrm{c})$ & 20 & & $225(\mathrm{q})$ & $5(\mathrm{~h})$ & 900 \\
\hline
\end{tabular}

Source: own elaboration.

Note: (a) Added after fermentation; (b) Fresh cow manure; (c)Unrefined brown sugar; (d) Maize stalks; (e) Pulque; (f) Oat bran; (g) Oat straw; (h) Yeast; (i) Charcoal; (j) Soil; (k) Refined sugar; (l) Beer; (m) Stinging nettle; (n) Maize stubbles; (o) Lime; (p) Chicken dung; (q) Fruit waste.

All four FFF were digested in airtight barrel-like containers of $200 \mathrm{~L}$ with an airlock. After adding all ingredients, the barrels were filled with rainwater and locked. Twenty-one days afterward, the barrels were opened for a few minutes to check the consistency, color, smell as well as the temperature. Subsequently, they were stirred. This procedure was repeated weekly for five to nine weeks (depending on the formulation): B1 and B2 were ready after 39 days, B3 after 46 days, and B 4 after 60 days of fermentation. The following criteria were applied to identify a completely fertilized product: Vastly liquid (and not viscous) consistency, the absence of visible solid elements, widely translucent coloring, and smell like silage. 
Simultaneously, a solid fermented organic fertilizer (bokashi) was elaborated. $500 \mathrm{~kg}$ bokashi were produced of $200 \mathrm{~kg}$ fresh sheep manure collected from local stables; $5 \mathrm{~kg}$ unrefined brown sugar; $150 \mathrm{~kg}$ maize stubbles; $50 \mathrm{~kg}$ maize stalks; $200 \mathrm{~kg}$ approved forestal soil; $50 \mathrm{~kg}$ charcoal; and $1 \mathrm{~kg}$ yeast. Water was added as needed to moisturize the bokashi entirely.

\subsection{Agrobiodiversity and crop management}

As common in traditional polycropping arrangements in central Mexico, maize (landrace 'Criollo Blanco'), fava bean ('San Pedro Tlaltizapan'), and a squash landrace ('Criollo de guia') were seeded simultaneously. Maize and fava bean were each seeded at a density of 20000 plants ha $^{-1}$, squash at a density of 5000 plants ha ${ }^{-1}$.

All plots were exclusively rainfed. There were no explicit disease control measures. Weeds were removed manually, and pests were monitored with a yellow sticky trap (Table 4).

TABLE 4

Timetable of crop preparation, management, and harvest activities

\begin{tabular}{|ll}
\hline Date & \multicolumn{1}{c}{ Activity } \\
\hline 20.02 .2016 & Elaboration of FFF and bokashi \\
22.02 .2016 & Incorporation of well-rotted cow manure \\
03.03 .2016 & Application of bokashi \\
17.03 .2016 & Seeding of maize, fava bean, and squash \\
$01.04 .2016-01.08 .2016$ & Two-weekly application of FFF (total of 9 applications) \\
$06.06 .2016+25.06 .2016$ & Application of garlic tea (organic pesticide) \\
$27.06 .2016-04.09 .2016$ & Harvesting of squash (9 harvestings) \\
$10.08 .2016-15.09 .2016$ & Harvesting of fava beans (4 harvestings) \\
$31.08 .2016-25.11 .2016$ & Harvesting of maize (8 harvestings) \\
\hline
\end{tabular}

Source: own elaboration.

The following pests were observed: Agriotes sp., Aphis fabae Scopoli, Apion godmani Wagner, Chaetocnema pulicaria F. E. Melsheimer, Dalbulus maidis De Long, Diabrotica longimaizeis Say, Helicoverpa zea Boddie, Helix aspersa Müller, Macrodactylus spp., Phyllophaga spp., Rhopalosiphum maidis Fitch, Sphenophorus spp., and Spodoptera frugiperda Walker (all at minor incidence). Only Diabrotica undecimpunctata Mannerheim showed a precariously growing population on fava beans, which is why it had to be controlled with organic pest management consisting of a tea of garlic and wood ash, which was applied twice (dose: $2 \mathrm{~L} \mathrm{ha}^{-1}$ per treatment at a dilution of 1:50 with rainwater) in June. Thanks to the use of this organic pesticide and due to increasing precipitations in summer, no additional pest control measures were necessary.

With the onset of the raining season in June, the following diseases were observed: Common rust (Puccinia sorghi Schweinitz) with maize; chocolate spot disease (Botritis fabae Sardiña), fusarium wilt (Fusarium spp.), and Peronospora viciae de Bary with fava bean; as well as Sphaerotheca sp. with squash (all at minor incidence). At the end of the harvesting period, faba bean rust, Uromyces fabae (Pers.) Schröt, seriously affected fava beans but did not harm the output.

As for weeds, the following species were identified:: Medicago lupulina L. Medicago polymorpha L., Melilotus indica (L.) All., Trifolium repens L., Trifolium pratense L. (legume species, which were partially tolerated), Asclepias linaria Cav., Brassica nigra (L.) W. D. J. Koch, Brassica rapa L., Commelina erecta L., Lopezia racemosa Cav., and Rumex crispus L. (observed at high density); as well as Avena fatua L., Bidens odorata Cav., Calandrinia micrantha Schltdl., Chenopodium album L., Hilaria cenchroides Kunth, Phalaris minor Retz., Sinapis alba L., and Taraxacum spp. (at minor incidence). 
To provide basic fertilization for germination and initial vegetative growth, 23 days before seeding, a basic fertilization of $10 \mathrm{t} \mathrm{ha}^{-1}$ rotted cow manure was incorporated at a depth of $15 \mathrm{~cm}$. In the treatment with bokashi, additional $10 \mathrm{t} \mathrm{ha}^{-1}$ of bokashi were incorporated 14 days before seeding.

Before their application, all FFF were diluted 1:20 with rainwater. Fourteen days after seeding (DAS), the respective treatments received the first application of the liquid fertilizers. This was repeated eight times in a twoweek interval. Through these applications, each plant received approximately $100 \mathrm{ml}$ of the correspondent FFF.

\section{5. Response variables and statistical analysis}

The following variables were evaluated in the analysis of the FFF and the bokashi: $\mathrm{pH}$; electric conductivity; organic matter; and content of C, N, P, K, Ca, Mg, Na, and Fe. The carbon content was determined using dry combustion. Total Kjeldahl $\mathrm{N}$ was determined spectrophotometrically using chromotropic acid for extraction. P was also analyzed with a spectrophotometer. $\mathrm{K}$ (wavelength: $766 \mathrm{~nm}$ ) and $\mathrm{Na}(589 \mathrm{~nm}$ ) were determined using a flame photometer. Standard solutions were prepared by the dilution of stock solutions containing $\mathrm{K}^{+}$and $\mathrm{Na}^{+}$respectively. For the analysis of $\mathrm{Ca}$ ( $423 \mathrm{~nm}), \mathrm{Mg}(285 \mathrm{~nm})$, and $\mathrm{Fe}(510 \mathrm{~nm})$, an atomic absorption photometer with direct aspiration was used. For the analysis of $\mathrm{Ca}$ and $\mathrm{Mg}$, standard solutions with $\mathrm{Ca}^{2+}, \mathrm{Mg}^{2+}$, and lanthanum chloride were used. Regarding Fe, diluted nitric acid was added instead of lanthanum chloride (Secretaría de Medio Ambiente y Recursos Naturales, 2002).

In the case of maize, the weight of fresh cobs was measured 135 and 200 DAS. 200 DAS, the number of cobs and leaves per maize plant as well as the plant height were also determined. Fresh pods of the fava bean were weighed at 70,90, and 110 DAS. The plant height and the number of leaves per fava bean plant were determined at 154 DAS. For squash, the number of flowers per plant was measured ten times between 30 and 178 DAS and then summarized. For all crops, the total yield per area was determined. Maize was harvested nine times between 135 DAS and 220 DAS. Fava bean was harvested four times in a biweekly interval, starting at 160 DAS and ending at 202 DAS. Squash was harvested eight times, 45 to 178 DAS (Table 4).

Additionally, the Land Equivalent Ratio $(L E R)$ was calculated. It refers to the monoculture area required to generate the same yield as in 1 ha of the analyzed polyculture system and provides a standardized basis to compare monocropping and polycropping systems:

$$
L E R=\sum_{i=1}^{n} \frac{Y P_{i}}{Y M_{i}}
$$

where $n$ corresponds to the number of associated crops, $Y P$ to the yield per hectare of a crop in polyculture and $Y M$ to the yield of the same crop in monoculture (grown under similar conditions). An $L E R>1.0$ expresses a productive advantage of a polyculture. Maize, fava bean, and squash yields in nearby low-input monocropping systems were used as reference values.

The normality of distribution of means was tested using the Shapiro-Wilk test. The homogeneity of variances was assessed with the Levene test. Significant differences were determined using a one-way ANOVA and post-hoc analysis with a Tukey test $(p \leq 0.05)$ for the following parameters: total yield per area of each crop, fruit weight of each crop at different stages, cobs per plant (maize), flowers and harvestable fruits per plant (squash), plant height (maize and fava bean), and the number of leaves (maize and fava bean).

\section{Results}

\section{1. Analysis of FFF}

As Table 5 shows, B1, B3, and B4 were slightly alkaline, and B2 was strongly alkaline. The four applied FFF showed a salinity between $0.13 \mathrm{dS} \mathrm{cm}-1$ (B3) and $1.02 \mathrm{dS} \mathrm{cm}-1$ (B2). With $2306 \mathrm{ppm}, \mathrm{B} 2$ showed the highest 
mineral N content. Regarding P, Ca, and Mg content, B2 was also among the most nutritive treatments, while B1 showed the highest $\mathrm{K}$ content.

TABLE 5

Chemical properties and composition of the examined fermented liquid fertilizers (B1-B4) and the bokashi (BO)

\begin{tabular}{|c|c|c|c|c|c|c|}
\hline & $\mathrm{pH}$ & $\mathrm{C}$ org & $\mathrm{OM}^{(\mathrm{a})}$ & $\mathrm{EC}^{(\mathrm{b})}$ & $\mathrm{N}(\mathrm{c})$ & $\mathrm{P}$ \\
\hline & & $\%$ & $\%$ & $\mathrm{dS} \mathrm{cm} \mathrm{cm}^{-1}$ & ppm & --- \\
\hline $\mathrm{BO}(\mathrm{d})$ & $8.27 \pm 0.21$ & $33.54 \pm 2.1$ & $29.13 \pm 3.5$ & $9.05 \pm 0.07$ & $19100 \pm 674$ & $4404 \pm 111$ \\
\hline B1 & $7.68 \pm 0.14 b^{(e)}$ & $0.49 \pm 0.03 \mathrm{a}$ & $32.1 \pm 1.1 \mathrm{a}$ & $0.82 \pm 0.01 \mathrm{~b}$ & $2101 \pm 103 \mathrm{a}$ & $2709 \pm 806 a$ \\
\hline B2 & $9.21 \pm 0.09 \mathrm{a}$ & $0.17 \pm 0.02 b$ & $24.2 \pm 5.6 b$ & $1.03 \pm 0.04 \mathrm{a}$ & $2306 \pm 87 \mathrm{a}$ & $2306 \pm 717 \mathrm{a}$ \\
\hline B3 & $7.33 \pm 0.02 b$ & $0.46+ \pm 0.09 a$ & $12.4 \pm 7.0 \mathrm{~b}$ & $0.31 \pm 0.06 \mathrm{c}$ & $1288 \pm 205 b$ & $949 \pm 52 b$ \\
\hline \multirow[t]{3}{*}{ B4 } & $7.52 \pm 0.12 b$ & $0.33 \pm 0.1 \mathrm{a}$ & $2.5 \pm 4.3 \mathrm{c}$ & $0.13 \pm 0.1 \mathrm{~d}$ & $132 \pm 87 \mathrm{c}$ & $113 \pm 29 c$ \\
\hline & $\mathrm{K}$ & $\mathrm{Ca}$ & $\mathrm{Mg}$ & $\mathrm{Na}$ & $\mathrm{Fe}$ & \\
\hline & --- & --- & --- & --- & --- & \\
\hline $\mathrm{BO}(\mathrm{d})$ & $30963 \pm 1385$ & $22014 \pm 1400$ & $2097 \pm 88$ & $1292 \pm 44$ & $1769 \pm 31$ & \\
\hline B1 & $4493 \pm 103 a$ & $3716 \pm 122 b$ & $1499 \pm 96 a$ & $12 \pm 2 \mathrm{a}$ & $0.49 \pm 0.02 \mathrm{a}$ & \\
\hline B2 & $3929 \pm 121 b$ & $13026 \pm 169 a$ & $1384 \pm 104 \mathrm{a}$ & $13 \pm 0 \mathrm{a}$ & $0.17 \pm 0.08 b$ & \\
\hline B3 & $3306 \pm 494 b$ & $2118 \pm 110 \mathrm{c}$ & $705 \pm 56 b$ & $14 \pm 0 \mathrm{a}$ & $0.46 \pm 0.06 \mathrm{a}$ & \\
\hline B4 & $377 \pm 85 \mathrm{c}$ & $238 \pm 134 \mathrm{~d}$ & $117 \pm 35 \mathrm{c}$ & $7 \pm 4 \mathrm{a}$ & $0.33 \pm 0.07 \mathrm{a}$ & \\
\hline
\end{tabular}

Source: own elaboration.

Note: (a) Organic matter; (b) Electric conductivity; (c)Total Kjeldahl N; (d) Since (compared to FFF) bokashi is characterized by a different consistency and preparation process, it was not considered in the statistical analysis; (e) Different letters in the same column indicate significant differences based on a one-way ANOVA and a post-hoc analysis using Tukey-Test $(p \leq 0.05)$.

\section{2. Growth and yield performance}

The highest maize yield was obtained in treatment B2 (Table 6). Since there were minor differences regarding fava bean and squash yield among all treatments, maize output was decisive for the total yield performance of the polycropping system. B2 consequently provided the highest $L E R$ of 1.26 , while the other treatments showed LER below 1.0 (Table 7).

\section{TABLE 6}

Total maize yield per area, weight of single corncobs, number of cobs per plant, plant height, and number of leaves per maize plant in control treatment (c), and treatments with four different fermented liquid fertilizers (B1-B4) and with bokashi (BO)

\begin{tabular}{|lcccccc}
\hline & Total yield & $\begin{array}{c}\text { Fruit weight 135 } \\
\text { DAS (a) }\end{array}$ & $\begin{array}{c}\text { Fruit weight 200 } \\
\text { DAS }\end{array}$ & Cobs per plant & $\begin{array}{c}\text { Plant height 200 } \\
\text { DAS }\end{array}$ & $\begin{array}{c}\text { Number of leaves } \\
\text { 200 DAS }\end{array}$ \\
\hline & $\mathrm{kg} \mathrm{ha}^{-1}$ & $\mathrm{~g}$ & $\mathrm{~g}$ & $\mathrm{~g}$ & $\mathrm{~cm}$ & \\
$\mathrm{C}$ & $1766 \pm 44 \mathrm{c}$ (b) & $66 \pm 31 \mathrm{c}$ & $189 \pm 9 \mathrm{a}$ & $1.13 \pm 0.11 \mathrm{~b}$ & $130 \pm 3 \mathrm{~b}$ & $6 \pm 0 \mathrm{a}$ \\
BO & $1636.4 \pm 31 \mathrm{c}$ & $53 \pm 2 \mathrm{c}$ & $182 \pm 31 \mathrm{a}$ & $1.09 \pm 0 \mathrm{~b}$ & $125 \pm 4 \mathrm{~b}$ & $7 \pm 0 \mathrm{a}$ \\
B1 & $2261.4 \pm 56 \mathrm{~b}$ & $104 \pm 13 \mathrm{bc}$ & $229 \pm 18 \mathrm{a}$ & $0.79 \pm 0.08 \mathrm{~b}$ & $131 \pm 2 \mathrm{~b}$ & $7 \pm 1 \mathrm{a}$ \\
B2 & $4788.9 \pm 167 \mathrm{a}$ & $180 \pm 4 \mathrm{ab}$ & $171 \pm 9 \mathrm{a}$ & $1.02 \pm 0.01 \mathrm{~b}$ & $154 \pm 4 \mathrm{a}$ & $6 \pm 1 \mathrm{a}$ \\
B3 & $2217.5 \pm 102 \mathrm{~b}$ & $232 \pm 14 \mathrm{a}$ & $195 \pm 15 \mathrm{a}$ & $2.42 \pm 0.03 \mathrm{a}$ & $150 \pm 5 \mathrm{a}$ & $6 \pm 0 \mathrm{a}$ \\
B4 & $1535.4 \pm 90 \mathrm{c}$ & $122 \pm 8 \mathrm{~b}$ & $126 \pm 14 \mathrm{~b}$ & $0.77 \pm 0.02 \mathrm{~b}$ & $156 \pm 3 \mathrm{a}$ & $6 \pm 0 \mathrm{a}$ \\
$p$ & 0.027 & 0.043 & 0.039 & 0.012 & 0.037 & 0.758 \\
\hline
\end{tabular}

Source: own elaboration.

Note: (a) Days after seeding; (b) Different letters in the same column indicate significant differences based on a one-way ANOVA and a post-hoc analysis using Tukey-Test $(p \leq 0.05)$. 
TABLE 7

Total maize, fava bean, and squash yield and consequent land equivalent ratio (based on referential monocropping yields) in control treatment (c) and treatments with four different fermented liquid fertilizers (B1-B4) as well as bokashi (BO)

\begin{tabular}{|llccc}
\hline Treatment & \multicolumn{1}{c}{ Maize total yield } & Fava bean total yield & Squash total yield & Land Equivalent Ratio \\
\hline & \multicolumn{1}{c}{$\mathrm{kg} \mathrm{ha}^{-1}$} & $\mathrm{~kg} \mathrm{ha}^{-1}$ & $\mathrm{~kg} \mathrm{ha}^{-1}$ & \\
C & 1766 & 1330.4 & 3670.2 & 0.90 \\
BO & 1636.4 & 740.3 & 2129 & 0.58 \\
B1 & 2261.4 & 633.35 & 5677 & 0.98 \\
B2 & 4788.9 & 1397.4 & 3809 & 1.26 \\
B3 & 2217.5 & 1741.97 & 2085 & 0.89 \\
B4 & 1535.4 & 1194.75 & 1486 & 0.62 \\
Reference Yield (a) & 9000 & 4000 & 10000 & \\
\hline
\end{tabular}

Source: own elaboration.

Note: (a) The reference yield considers the monocropping output of the respective crops (same varieties, similar crop management) in central Mexico.

Maize germinated earliest in B3 (Figure 1). 135 DAS, B3 also showed the highest cob number and weight. Gradually, more and more plants died in this treatment. 240 DAS, 43\% of the maize plants in B3 had died.

In contrast, bokashi resulted in most vital maize plants 240 DAS. Yet, its yield performance was poor (Table 7). From 30 DAS, B1 and B4 showed a continuously declining maize population. B1 and bokashi resulted in shorter maize plants compared to treatments B2, B3, and B4 (Table 6).

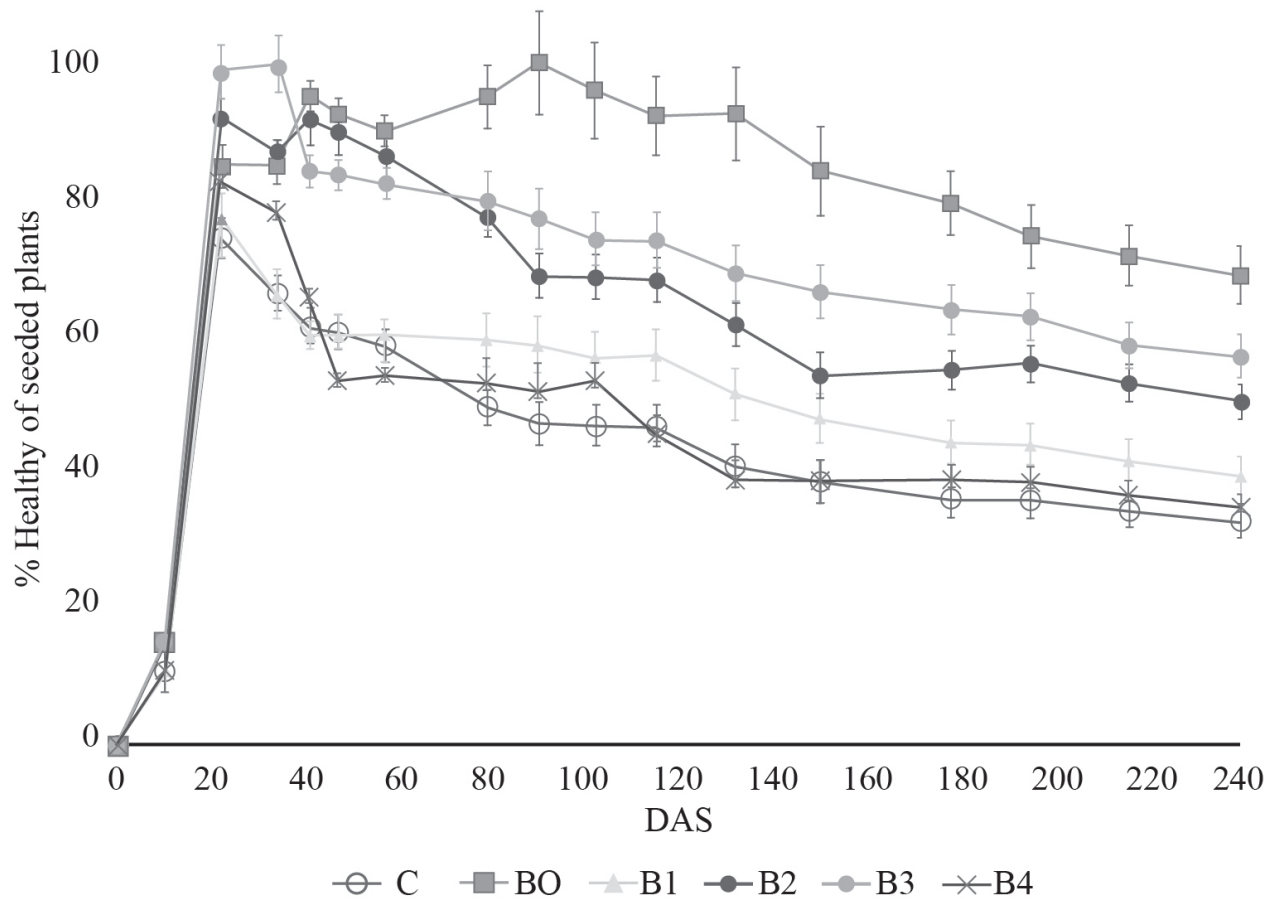

FIGURE 1

Survival of maize plants referred to each treatment (scatter bars show standard deviation): B3 caused the fastest germination, bokashi the highest survival rate

Source: own elaboration. 
Regarding fava bean, the control treatment was the fastest germinating and resulted in most living plants (Figure 2) as well as in the highest number of leaves per plant (Table 8). B3 showed a similar survival rate but generated a higher yield than $\mathrm{B} 2$ due to the production of the heaviest pods of all treatments. The other treatments underperformed $\mathrm{B} 2$ and $\mathrm{B} 3$ in all parameters.

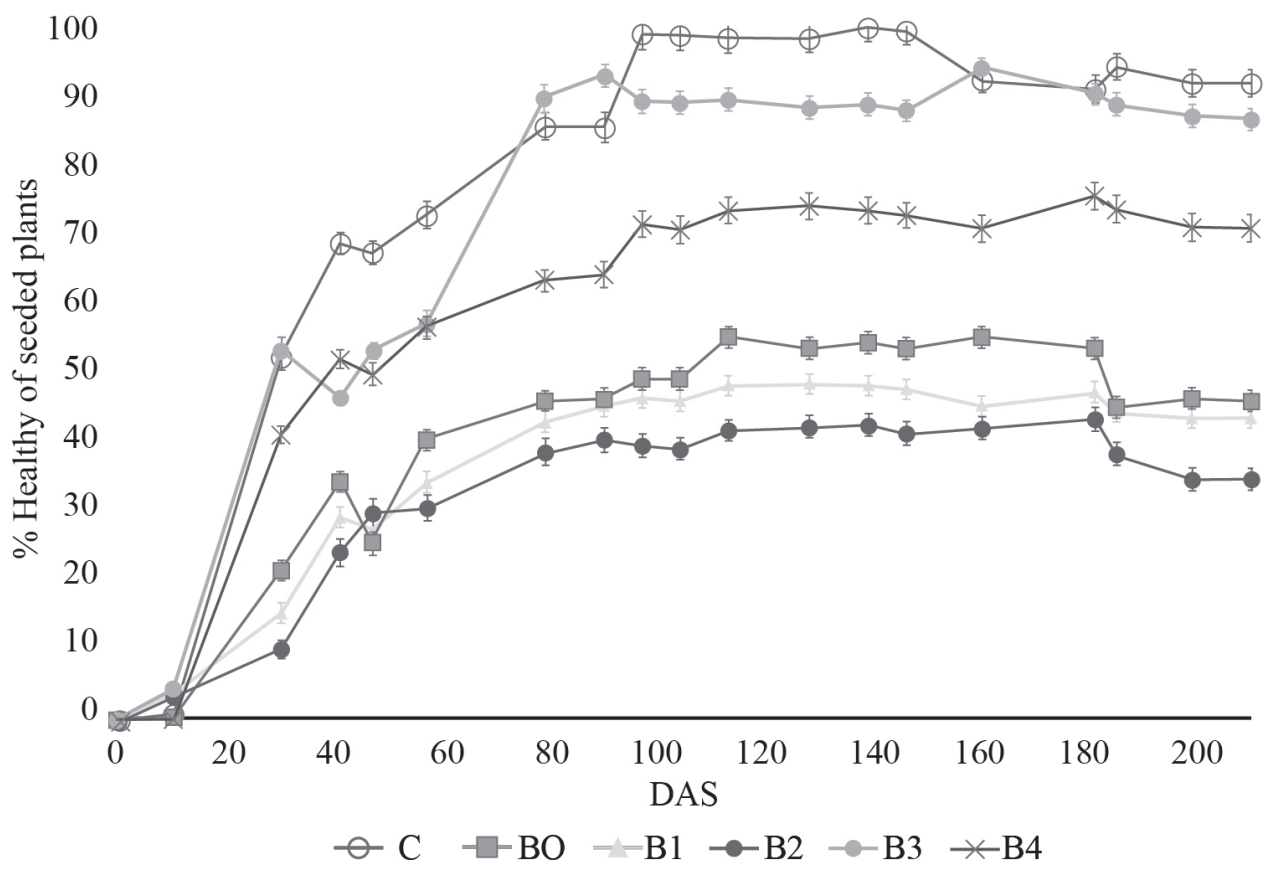

FIGURE 2

Survival rate of fava bean plants referred to each treatment (scatter bars show standard deviation): The control treatment caused the fastest germination; together with treatment B3, it also showed the highest survival rate $240 \mathrm{DA}$

Source: own elaboration.

TABLE 8

Total yield per area, weight of single pods, plant height, and number of leaves of fava bean in control treatment $(\mathrm{c})$ and treatments with four different fermented liquid fertilizers (B1-B4) as well as bokashi (BO)

\begin{tabular}{|lcccccc}
\hline Treatment & $\begin{array}{c}\text { Total yield } \\
\text { fresh pod })\end{array}$ & $\begin{array}{c}\text { Fresh pod } \\
\text { weight 70 DASZ }\end{array}$ & $\begin{array}{c}\text { Fresh pod } \\
\text { weight 90 DAS }\end{array}$ & $\begin{array}{c}\text { Fresh pod } \\
\text { weight 110 DAS }\end{array}$ & $\begin{array}{c}\text { Plant height } \\
\text { 154 DAS }\end{array}$ & $\begin{array}{c}\text { Number of } \\
\text { leaves 154 DAS }\end{array}$ \\
\hline & $\mathrm{kg} \mathrm{ha}^{-1}$ & $\mathrm{~g}$ & $\mathrm{~g}$ & $\mathrm{~g}$ & $\mathrm{~cm}$ & \\
$\mathrm{C}$ & $1330.4 \pm 117 \mathrm{ab}(\mathrm{b})$ & $16.45 \pm 0.43 \mathrm{a}$ & $15.28 \pm 0.94 \mathrm{ab}$ & $17.02 \pm 0.06 \mathrm{ab}$ & $94 \pm 2 \mathrm{ab}$ & $20.43 \pm 1.03 \mathrm{~b}$ \\
$\mathrm{BO}$ & $740.3 \pm 39 \mathrm{~b}$ & $17.96 \pm 0.95 \mathrm{a}$ & $18.02 \pm 0.29 \mathrm{a}$ & $15.96 \pm 0.41 \mathrm{ab}$ & $81 \pm 6 \mathrm{~b}$ & $15.75 \pm 1.11 \mathrm{c}$ \\
$\mathrm{B} 1$ & $633.35 \pm 44 \mathrm{~b}$ & $12.53 \pm 0.8 \mathrm{a}$ & $13.84 \pm 0.11 \mathrm{~b}$ & $15 \pm 0.11 \mathrm{ab}$ & $83 \pm 1 \mathrm{~b}$ & $17.04 \pm 0.99 \mathrm{~b}$ \\
$\mathrm{~B} 2$ & $1397.4 \pm 86 \mathrm{ab}$ & $13.58 \pm 0.61 \mathrm{a}$ & $15.47 \pm 0.66 \mathrm{ab}$ & $15.31 \pm 0.45 \mathrm{ab}$ & $111 \pm 5 \mathrm{a}$ & $30.42 \pm 1.56 \mathrm{a}$ \\
$\mathrm{B} 3$ & $1741.97 \pm 75 \mathrm{a}$ & $19.31 \pm 0.31 \mathrm{a}$ & $17.31 \pm 0.51 \mathrm{ab}$ & $19.32 \pm 1.18 \mathrm{a}$ & $104 \pm 2 \mathrm{a}$ & $21.4 \pm 0.86 \mathrm{~b}$ \\
$\mathrm{~B} 4$ & $1194.75 \pm 224 \mathrm{ab}$ & $18.23 \pm 0.16 \mathrm{a}$ & $13.39 \pm 0.21 \mathrm{~b}$ & $14.08 \pm 0.7 \mathrm{~b}$ & $95 \pm 7 \mathrm{ab}$ & $17.25 \pm 0.29 \mathrm{~b}$ \\
$p$ & 0.054 & 0.027 & 0.038 & 0.26 & 0.013 & 0.044 \\
\hline
\end{tabular}

Source: own elaboration.

Note: (a) Days after seeding; (b) Different symbols in the same column indicate significant differences based on a one-way ANOVA and a post-hoc analysis using Tukey-Test $(p \leq 0.05)$. 
The survival rate of squash was generally low: 180 DAS, B1 provided 51\% vital squash plants, while the other treatments showed values below 50\% (Figure 3). As shown in Table 9, B1 produced the highest squash yield. B1 and the control treatment resulted in most flowers per plant.

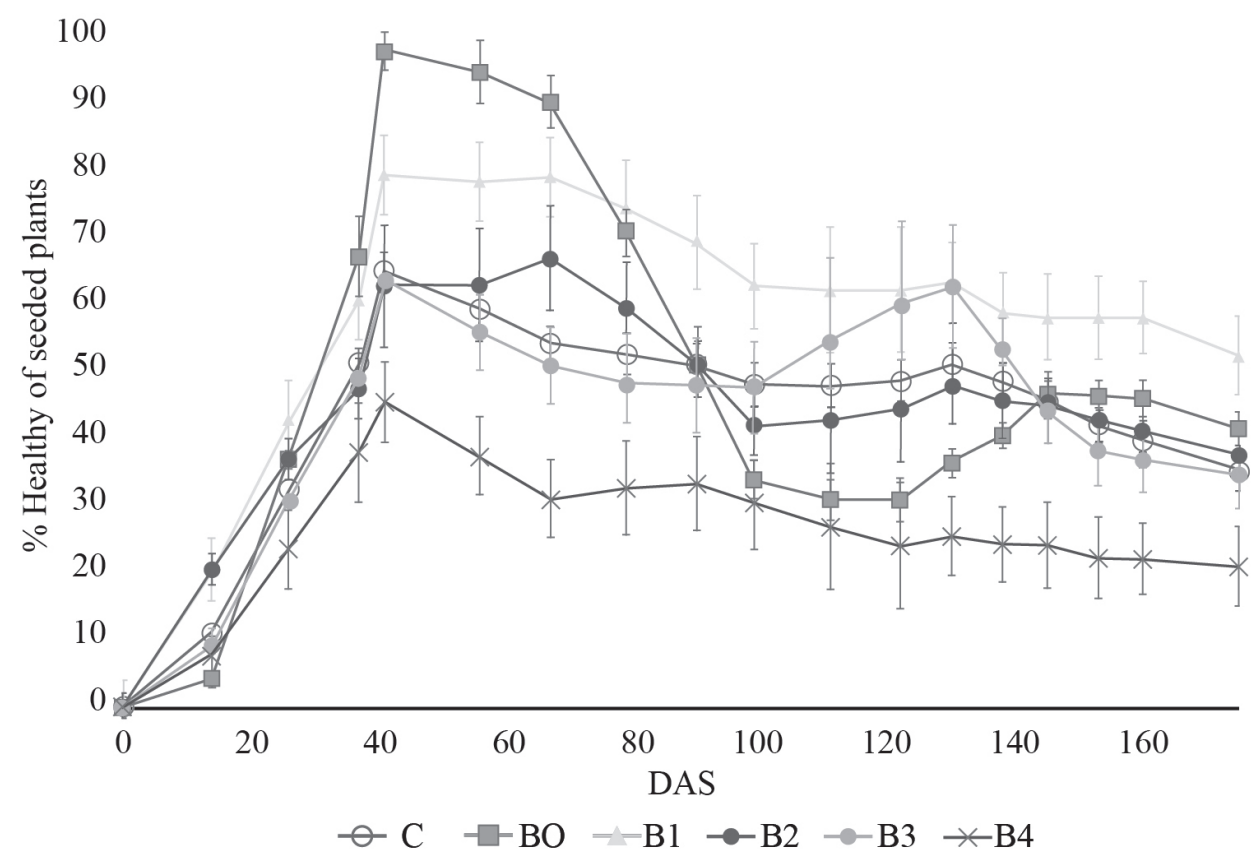

FIGURE 3

Survival rate of squash plants referred to each treatment (scatter bars show standard deviation): The use of bokashi resulted in the fastest germination. Treatment B1 showed the highest survival rate 240 DAS

Source: own elaboration.

TABLE 9

Total yield per area, weight of single fruits, number of flowers, and number of harvestable fruits per plant of squash in a control treatment (c), and treatments with four different fermented liquid fertilizers (B1-B4) as well as bokashi (BO)

\begin{tabular}{|c|c|c|c|c|}
\hline & Total yield & Fruit weight & Flowers per plant & Harvestable fruits per plant \\
\hline & $\mathrm{kg} \mathrm{ha}^{-1}$ & g & & \\
\hline $\mathrm{C}$ & $3670.2 \pm 87 b^{(a)}$ & $244 \pm 11 b$ & $36 \pm 1 \mathrm{a}$ & $21 \pm 3 \mathrm{a}$ \\
\hline $\mathrm{BO}$ & $2129.9 \pm 144 b$ & $195 \pm 10 b$ & $17 \pm 0.2 \mathrm{c}$ & $13 \pm 2 b$ \\
\hline B1 & $5677.6 \pm 309 a$ & $262 \pm 53 \mathrm{ab}$ & $31 \pm 3 \mathrm{ab}$ & $23 \pm 1 \mathrm{a}$ \\
\hline $\mathrm{B} 2$ & $3800.9 \pm 284 b$ & $357 \pm 40 \mathrm{a}$ & $24 \pm 0.2 b$ & $15 \pm 0.1 \mathrm{~b}$ \\
\hline B3 & $2085.3 \pm 140 \mathrm{~b}$ & $231 \pm 21 b$ & $25 \pm 2 b$ & $15 \pm 2 b$ \\
\hline B4 & $1486.2 \pm 365 \mathrm{c}$ & $223 \pm 8 b$ & $21 \pm 0.1 b$ & $11 \pm 2 b$ \\
\hline$p$ & 0.038 & 0.072 & 0.009 & 0.045 \\
\hline
\end{tabular}

Source: own elaboration.

Note: (a) Different symbols in the same column indicate significant differences based on a one-way ANOVA and a post-hoc analysis using Tukey-Test $(p \leq 0.05)$. 


\section{Discussion}

\section{1. Analysis of FFF}

Although FFF usually have a pH of around 6.0 (Zagoya et al., 2015), all analyzed FFF were alkaline (Table 5). The elevated $\mathrm{pH}$ in $\mathrm{B} 1$ and $\mathrm{B} 2$ is related to the used wood ash originating from the domestic fuel of pine wood. Such ash is commonly alkaline, especially if the burning temperatures are not extremely high (Etiégni \& Campbell, 2005). Charcoal made of pine wood (as used in B2) is a further trigger of alkalinity (Briggs, 2005). In the case of B3, high pH is related to the use of lime (Arman \& Munfakh, 1970). In B4, the used chicken manure increased the $\mathrm{pH}$ (Wang et al., 2012). The $\mathrm{pH}$ of 9.2 measured in $\mathrm{B} 2$ requires special attention because such elevated alkalinity decreases the microbial activity. Likely, anaerobic digestion resulted in accumulation of alkaline biogenic amines (Chen et al., 2008). Unique ingredients of B2 were pulque, oat bran, oat straw, and charcoal.

B1, B2, and B3 showed a higher EC than common in FFF (Orellana et al., 2013), which is prevailingly related to the high nutrient content of these treatments (Tables 1, 5).

$\mathrm{B} 2$ showed the highest, $\mathrm{B} 1$ the second-highest $\mathrm{N}$ content. The same amount of cow manure was used in both treatments. The main difference between B1 and B2 consisted in the used energy sources and inoculants: unrefined brown sugar was used as the energy source in B1, pulque in B2; respectively, milk was the inoculant in $\mathrm{B} 1$, while oat bran and yeast were used in $\mathrm{B} 2$. The total raw protein content of these ingredients is $131.8 \mathrm{~g} \mathrm{~L}^{-1}$ unfermented raw material in B2, but only $12.56 \mathrm{~g} \mathrm{~L}^{-1}$ in B1 (De Leon et al., 2005), which explains the higher $\mathrm{N}$ content of B2. Denitrification is a potential trigger of $\mathrm{N}$ losses but was not assessed.

Concerning P content, B1 and B2 also outperformed the other treatments. The high content of mineralized P is an indicator of a complete fermentation process (Galindo et al., 2007). Cow manure was the most significant $\mathrm{P}$ source in both treatments. Additionally, the ash added to B1 and B2 supplied $8.4 \mathrm{~g} \mathrm{~kg}^{-1} \mathrm{P}$ but also $0.6 \mathrm{~g} \mathrm{~kg}^{-1}$ $\mathrm{Na}$ (Misra et al., 1993), which explains why these treatments contained most Na.

Apart from cattle manure and wood ash, fermented maize stalks are an important $\mathrm{K}$ source (Darwish et al., 2012). Consequently, B1 showed the highest $\mathrm{K}$ content. Finally, B2 contained most $\mathrm{Ca}$ and $\mathrm{Mg}$, which is related to the use of ash and charcoal (Briggs, 2005).

\section{2. Growth and yield performance of maize}

Since young leaves are more penetrable for nutrients than fully-expanded ones (Fernández \& Eichert, 2009), the application of FFF affected the vegetative development of all crops positively at an early stage. A quick vegetative growth (enabled through foliar $\mathrm{N}$-input) is the base for a satisfactory maize output (Aguilar $e$ t al., 2015). The foliar supply of $P$ at the final stage of vegetative growth is a further stimulus of a maize output (Fageria et al., 2009). Consequently, B2, the treatment that contained most $\mathrm{N}$ and P, provided the highest maize yield (Table 6).

Fertilization with bokashi resulted in more surviving maize plants than when FFF were used, which indicates a tendentially limiting effect of FFF on the maize survival rate. However, bokashi did not result in a satisfactory yield. This circumstance is mainly attributed to a low early maize yield (Table 6), a consequence of a low $\mathrm{N}$ and P supply during the initial growth stages.

The remarkable low survival of maize plants treated with B1 is attributed to the elevated $\mathrm{K}$ content of this FFF, which decreased the availability of other nutrients (Restrepo \& Hensel, 2009). The equally low maize survival rate of B4 is related to generally low nutrient supply. Accordingly, plants treated with B4 showed the lowest cob weight. 


\section{3. Growth and yield performance of fava bean}

The yield response of the fava bean was relatively constant among all treatments, indicating that this legume (compared to maize and squash) demands less additional fertilization measures in a polycropping arrangement (Table 8).

Although B2 and B3 showed a similar fava bean survival rate, B3 produced heavier pods and a consequently higher yield. There is evidence that rhizospheric salinity affects the association between a fava bean and N-fixing bacteria and that this condition favors the accumulation of macronutrients in the vegetative organs instead of the fruits (Cordovilla et al., 2008). Simultaneously, salinity decreases the overall $\mathrm{K}, \mathrm{Mg}, \mathrm{Ca}$, and S content of fava beans (Abdelhamid et al., 2010). There is no evidence whereby the salinity of organic foliar applications has similar consequences. However, salinity may explain why B3 (with a lower EC and significantly less $\mathrm{Na}$ ) yielded more fava bean than $\mathrm{B} 2$ (which was richer in $\mathrm{N}$ and $\mathrm{P}$ ).

Additionally, B2 stimulated a quick maize growth, which resulted in stronger competition for sunlight between maize and the (shorter) fava beans. Since sunlight stimulates the stomatal opening (Fernández \& Eichert, 2009), the higher the maize plants grew, the lower was the efficiency of the FFF applied to the fava beans.

\section{4. Growth and yield performance of squash}

Competition for light affected the squash yield, causing a generally low survival rate of this crop. Only B1 provided more than 50\% vital squash plants and was consequently the highest yielding treatment. Of all experimented FFF, $\mathrm{B} 1$ contained most $\mathrm{K}$; and for cucurbits, there is evidence of a satisfactory yield response to foliar $\mathrm{K}$ supply (Bejarano \& Méndez 2004).

\section{5. Land Equivalent Ratio}

While all other treatments resulted in less yield than comparable monocropping arrangements with each, maize, squash, or fava bean (LER below 1.0), B2 provided 26\% more output than comparable monocropping systems (Table 9). This was caused by high maize yield of B2 of $4788.9 \mathrm{~kg} \mathrm{ha}^{-1}$. Regarding fava bean and squash, additional FFF applications may have increased their competitiveness against maize and consequently provided higher yields (Bejarano \& Méndez, 2004).

\section{Prospective analysis}

Fermented foliar fertilizers, together with biofertilizers, are already standard practice in small-scale farms in tropical regions of South American countries such as Ecuador. The results of this trial can contribute significantly to the adoption of these techniques in other parts of the world, for example in Mexico. The significance of this trial lies in the exclusive use of resources available in a temperate climate, which amplifies the geographical applicability of FFF. The experiment proved the functionality of using resources such as fermented food (pulque) instead of the so far indispensable tropical molasses. Additionally, the trial centered on the intercropping of maize, a staple crop. Using FFF in both polycropping systems and staple crops is a new approach for this plant nutrition strategy, which is more common in horticultural monocropping. Due to the significance of polycropping maize in traditional Mesoamerican farming, FFF are a viable option for thousands of peasants in the Mexican highlands and similar climates.

\section{Conclusions}

The present trial assessed the effect of the use of four FFF made of resources available in template central Mexico on the yield and the vegetative development of a polycropping system consisting of maize, fava bean, 
and squash. Three out of four experimented FFF formulations (B1, B2, B3) showed satisfactory nutrient content. Especially B2, made of cow manure, ash, pulque, oat bran, and yeast, was outstandingly nutritive and consequently delivered the highest maize yield in the observed polycropping system. Remarkably, B2 did not include fresh cow milk, which is commonly used as an inoculant of FFF, but pulque. Accordingly, pulque is a promising and regionally available substitute for milk. Nevertheless, the considerable alkalinity of $\mathrm{B} 2$ requires further microbiological analysis. It was also shown that FFF rich in $\mathrm{N}$ and $\mathrm{P}$ had a positive impact on maize yield, which is expected to be related to the immediate supply of these nutrients during the vegetative growth stage of the crop. his opens the possibility of using FFF as a macronutrient source. Despite the sustainability of polycropping systems and their significance for Mexico, a lesson learned from this trial is that the assessment of new FFF formulations would be easier in monocropping arrangements due to crop interactions in polycropping. For example, B2 strongly stimulated maize growth and yield; yet, the sound maize growth affected the development of the associated crops (fava bean and squash), mainly due to competition for sunlight. Furthermore, it diverse crops responded differently to FFF application: Fava bean yielded most with B3 (made of stinging nettle and cow manure); squash delivered most yield with B1 (based on a standard formulation). This indicates the need for developing specific FFF formulations for each crop. Thanks to an uncomplicated preparation process and the use of locally available resources, FFF are a sustainable option for sustainable farmers. Due to their "regionality", there won't be a standard manual for the preparation of FFF. The successful use of FFF requires innovative researchers and farmers all over the world.

\section{Agradecimientos}

Se agradecen los comentarios de los árbitros de la revista que mejoraron sustancialmente el contenido del artículo.

\section{REFERENCES}

Abdelhamid, M., Shokr, M., \& Bekheta, M. (2010). Growth, root characteristics, and leaf nutrients accumulation of four fava bean (Vicia fabaL.) cultivars differing in their broomrape tolerance and the soil properties in relation to salinity. Communications In Soil Science And Plant Analysis, 41(22), 2713-2728. https://doi.org/10.1080/00103624.2010.518263

Aguilar, C., Escalante, J. A., \& Aguilar, I. (2015). Análisis de crecimiento y rendimiento de maíz en clima cálido en función del genotipo, biofertilizante y nitrógeno. Terra Latinoamericana, 33(1), 51-62.

Altieri, M. A. (1994). Bases agroecológicas para una producción agrícola sustentable. Agricultura técnica, 54(4), 371-386.

Arman, A., \& Munfakh, G. (1970). Stabilization of organic soils with lime. Baton Rouge: Louisiana State University.

Bejarano, C., \& Méndez, H. (2004). Fertilización orgánica comparada con la fertilización quimica en el cultivo de fréjol (Phaseolus vulgaris, para minimizar el efecto de degradación del suelo. Universidad Técnica del Norte.

Briggs, C. (2005). Contributions of Pinus Ponderosa charcoal to soil chemical and physical properties. In The 2005 ASACSSA-SSSA International Annual Meeting (pp. 1-13). Salt Lake City: ASACSSA-SSSA.

Burnett, S., Mattson, N., \& Williams, K. (2016). Substrates and fertilizers for organic container production of herbs, vegetables, and herbaceous ornamental plants grown in greenhouses in the United States. Scientia Horticulturae, 208, 111-119. https://doi.org/10.1016/j.scienta.2016.01.001 
Chen, Y., Cheng, J. J., \& Cramer, K. S. (2008). Inhibition of anaerobic digestion process: A review. Bioresource technology, 99(10), 4044-4064. https://doi.org/10.1016/j.biortech.2007.01.057

Chojnacka, K. (2015). Innovative bio-products for agriculture. Open Chemistry, 13(1). https://doi. org/10.1515/chem-2015-0111

Comisión Nacional del Agua. (2018). Datos históricos de la estación meteorológica 15003, Almoloya de Juárez. Retrieved from http://smn1.conagua.gob.mx/index.php?option=com_content\&view=article\&i$\mathrm{d}=189 \& \mathrm{tmpl}=$ component

Cordovilla, M. P., Ocaña, A., Ligero, F., \& Lluch, C. (2008). Salinity effects on growth analysis and nutrient composition in four grain legumes-rhizobium symbiosis. Journal of Plant Nutrition, 18(8), 1595-1609. https://doi.org/10.1080/01904169509365006

Darwish, G., Bakr, A., \& Abdallah, M. (2012). Nutritional value upgrading of maize stalk by using Pleurotus ostreatus and Saccharomyces cerevisiae in solid state digestion. Annals of Agricultural Sciences, 57(1), 4751. https://doi.org/10.1016/j.aoas.2012.03.005

Ebel, R. (2017). Nachhaltige Pflanzenernährung mit fermentierten Blattdüngern. Gemüse, 541(10), 22-23.

Ebel, R., Kissmann, S. (2019). Fermented LeafFertilizers_Principles and Preparation. Organic Farming, 5(1), 14-23

Ebel, R., Pozas, J. G., Soría, F. S., \& Cruz, J. (2017). Manejo orgánico de la milpa: rendimiento de maíz, frijol y calabaza en monocultivo y policultivo. Terra Latinoamericana, 35(2), 149-70.

Etiégni, L. \& Campbell, A. G. (2005). Physical and chemical characteristics of wood ash. Bioresource Technology, 37(2), 173-178. https://doi.org/10.1016/0960-8524(91)90207-Z

Fageria, N. K., Barbosa, M. P., Moreira, A., \& Guimaraes, C. M. (2009). Foliar fertilization of crop plants. Journal of Plant Nutrition, 32(6), 1044-1064. https://doi.org/10.1080/01904160902872826

Fernández, V., \& Eichert, T. (2009). Uptake of hydrophilic solutes through plant leaves: Current state of knowledge and perspectives of foliar fertilization. Critical Reviews in Plant Sciences, 28(1-2), 36-68. https://doi. org/10.1080/07352680902743069

Galindo, A., Jerónimo, C., Spaans, E., \& Weil, M. (2007). Los abonos líquidos fermentados y su efectividad en plántulas de papaya (Carica papaya L.). Tierra Tropical, 3(1), 1-6.

Gerardi, M. (2003). The microbiology of anaerobic digesters. New York City: John Wiley \& Sons.

Gliessman, S. R. (1985). Multiple cropping systems: A basis for developing an alternative agriculture. Innovative biological technologies for lesser developed countries-Workshop proceedings (pp. 67-83). Washington D. C.: Congress of the USA, Office of Technology Assessment.

Instituto Nacional de Estadística y Geografía. (2018). Atlas nacional interactivo de México. Retrieved from http:// www.atlasdemexico.gob.mx/mapas3.html

Ito, S. (2006). Caracterización y evaluación de los factores que determinan la calidad nutricional e inocuidad en la producción de fertilizantes orgánicos fermentados. Centro Agronómico Tropical de Investigación y Enseñanza.

Kannan, S. (2010). Foliar fertilization for sustainable crop production. In E. Lichtfouse, Genetic engineering, biofertilisation, soil quality and organic farming (pp. 371-402). Heidelberg, Germany: Springer.

Lee, J., Kim, H., Lee, S., \& Ro, C. (2012). Evaluation of composted pig manure and organic fertilizer for organic onion production in paddy soil. Korean Journal of Horticultural Science and Technology, 30(2), 123-128.

De Leon, J. M., Borges, H., \& Camacho, E. (2005). Amino acid composition of some Mexican foods. Archivos Latinoamericanos de Nutrición, 55(1), 173-188.

Misra, M., Ragland, K., \& Baker, A. (1993). Wood ash composition as a function of furnace temperature. Biomass and Bioenergy, 4(2), 103-116. https://doi.org/10.1016/0961-9534(93)90032-y 
Orellana, T., Manzano, P., Chávez, E. Ruiz, O. \& León, R. (2013). Estándares de fermentación y maduración artesanal de Bioles. Yachana Revista Cientifica, 2(1), 1-7.

Restrepo, J., \& Hensel, R. (2009). Manual práctico de agricultura orgánica y panes de piedra. Cali: Impresora Feriva S. A.

Secretaría de Medio Ambiente y Recursos Naturales. (2002). Norma oficial mexicana NOM-SEMARNAT 2000. Mexico City: SEMARNAT.

Siura, S., Barrios, F., Delgado, J., Dávila, S., \& Chilet, M. (2009). Efectos del biol (abono orgánico líquido) en la producción de hortalizas. In M. A. Altieri (ed.), Vertientes del pensamiento agroecológico: fundamentos y aplicaciones (pp. 289-304). Medellín: SOCLA.

Vázquez, G. V., Magallón, R. F., \& Torres, L. F. C. (2014). Evaluación de biofertilizantes líquidos en la producción de elote y grano en maiz. e-Cucba, 1(1), 15-20.

Wang, X., Yang, F., Feng, Y., Ren, G., \& Han, X. (2012). Optimizing feeding composition and carbon-nitrogen ratios for improved methane yield during anaerobic co-digestion of dairy, chicken manure and wheat straw. Bioresource technology, 120(1), 78-83.

Zagoya, J., Ocampo, J., Ocampo, I., Macías, A., \& Peñaloza, P. D. (2015). Caracterización fisicoquímica de biofermentados elaborados artesanalmente. Biotechnia, 17(1), 4-19.

\section{BY-NC-ND}

